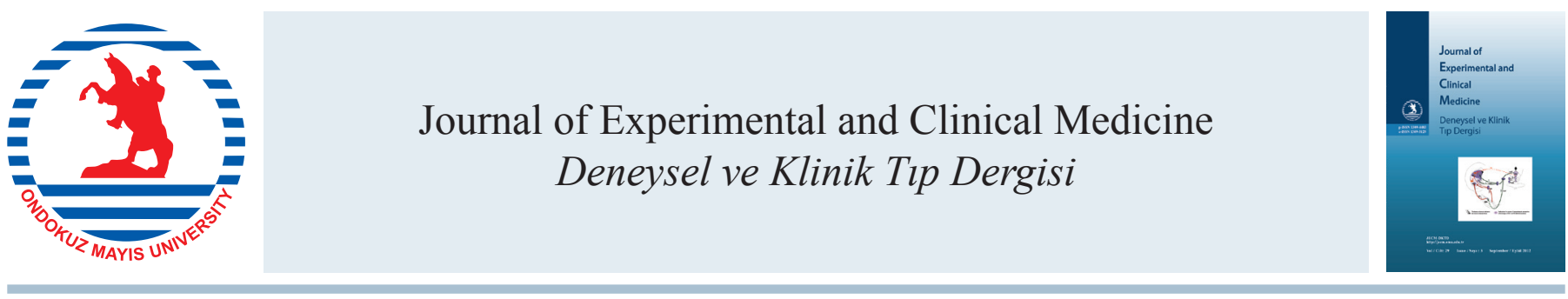

Case Report

doi: $10.5835 /$ jecm.omu.29.03.017

\title{
Down syndrome in both dichorionic twins: A case report
}

\author{
Dikoryonik ikizlerde Down sendromu: Bir olgu sunumu
}

Davut Güven*, Dürdane Yangal, İdris Koçak, Cazip Üstün

Department Obstetrics and Gynecology, Medical Faculty, Ondokuz Mayls University, Samsun, Turkey

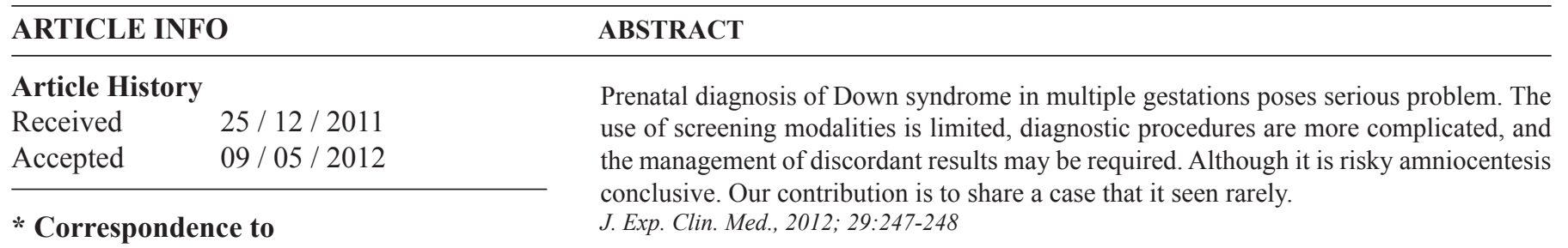

Davut Güven

Cumhuriyet Mahallesi

Atatürk Bulvarı 11. Sokak No:1

Bahadır Apartmanı D:6

Atakum, Samsun, Turkey

e-mail: dguven@omu.edu.tr

\section{ÖZET}

Çoğul gebeliklerde Down sendromunun prenatal tanı ciddi sorun teşkil etmektedir. Tarama yöntemlerinin kullanımı sınırlı olduğundan, tanı yöntemleri daha karmaşı ve yönetimi çelişkili sonuçlar doğurabilir. Bunun kesin tanısı riskli olmasına rağmen amniyosentezdir. Bu makalede nadir görülen bir durumu paylaşmak istedik. J. Exp. Clin. Med., 2012; 29:247-248

\section{Keywords:}

Prenatal diagnosis

Down syndrome

Nuchal translucency

Twin pregnancies

First trimester screening

Trisomy 21.

\author{
Anahtar Kelimeler: \\ Prenatal tanı \\ Down sendromu \\ Ense kalınlığ 1 \\ İkiz gebelikler \\ Birinci trimester tarama testi \\ Trizomi 21.
}

\section{Introduction}

The various methods of Down syndrome (DS) screening available for singletons (i.e. maternal age, first trimester screening (FTS) with nuchal translucency [NT] and serum screening, and second trimester maternal serum screening [MSS]) can also be used in twin pregnancies, although with lower detection rates. The performance of prenatal screening tests for the identification of trisomy 21 (Down syndrome) has markedly improved since the 1970s and early 1980s when maternal age was the sole mode of screening the general pregnant population. With the discovery of second trimester serum markers in the 1980s and 1990s and implementation of double, triple, and quad marker testing; the discovery of first trimester serum and ultrasound markers in the 1990s and implementation of the combined test; and the development of the integrated test and sequential screening strategies over the past decade, the performance of screening has improved to a detection rate of $90 \%-95 \%$ at a false positive rate of $2 \%-5 \%$ (Jacob, 2011). The addition of biochemistry may enhance first-trimester risk assessment in twin pregnancies (Chasen et al., 2007). In screening for trisomies, the correlation in NT measurements between the fetuses should be taken into account in the estimation of patient-specific risks (Wright et al., 2011). 


\section{Case}

We report such a case diagnosed prenatally. We carried out ultrasonography (US) to determine very thick nuchal translucency at 13 weeks' for both twins (Fig. 1).

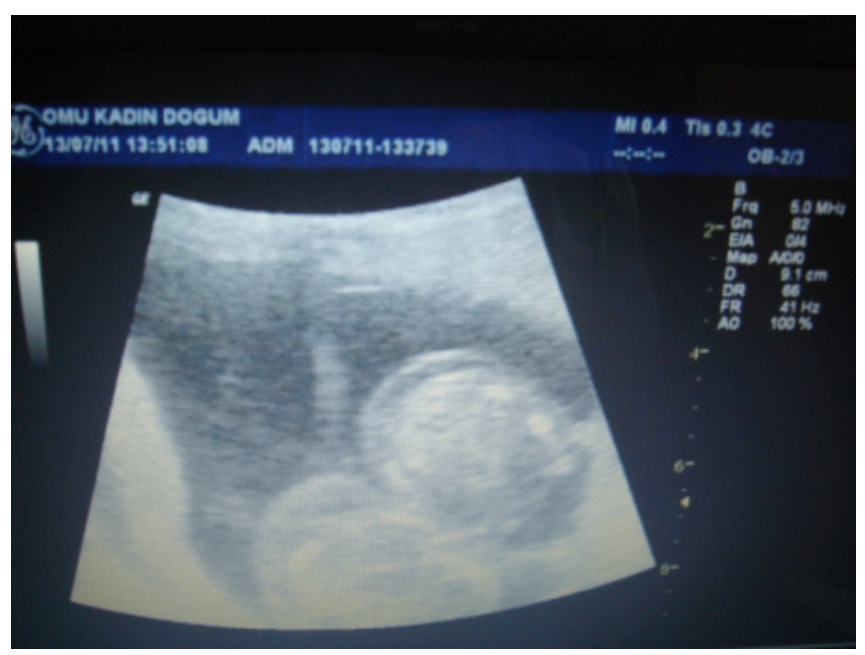

Fig. 1. Thick nuchal translucency in the both twins.

A 30-year-old woman, with a previous birth of a normal child and a current twin pregnancy diagnosed at seven weeks' gestation, was referred for counselling and amniocentesis at 18 weeks' gestation. Amniocentesis at 18 weeks' gestation was performed on both of the twin sacs, which confirmed Down syndrome. The results of both babies was found to be $47, \mathrm{XY},+21$ Termination of pregnancy was performed subsequently.

\section{Discussion}

Amniocentesis has an established record for safe and accurate diagnosis when sampling twins between 15 and 20 weeks' gestation, and continues to be the most frequently used met- hod. The technique, first described by Elias et al. in 1980, uses a 20 or 22-gauge spinal needle guided into one of the sacs under continuous ultrasound surveillance (Elias et al., 1980). After fluid is retrieved, the sac is 'marked' with dye (indigo carmine). A second needle is then used to sample the coexisting sac. Obtaining dye-free fluid ensures that the same sac has not been resampled. When higher order multiples are sampled, each sac can be marked in succession (Elias et al., 1980). We carried out US to determine the chorionicity. As diagnosis of chorionicity was critical in determining whether one or both twin amniotic sacs needed to be sampled, we requested for earlier US images to review before amniocentesis (Sin et al., 2009). Earlier US image taken at seven weeks showed two fetal poles and thick septum between the two. The review of early ultrasonography confirmed dichorionic twins. Amniocentesis at 18 weeks' gestation was performed on both of the twin sacs, which confirmed Down syndrome. The results of both babies was found to be $47, \mathrm{XY},+21$ Termination of pregnancy was performed subsequently. To achieve the level of performance possible today, serum markers must be combined with the fetal ultrasound marker, nuchal translucency, requiring close communication between the clinical laboratory and the obstetrical ultrasound unit. Invasive testing, either by the use of amniocentesis or chronic villus sampling (CVS), can be performed safely in twin and higher order multiple gestations, but pre-procedure counselling must address the unique aspects inherent for multiple gestations. Only experienced centers should perform these procedures because of the technical aspects as well as the expertise needed in handling discordant results. Overall, however, prenatal diagnosis in multiple gestations, either by the use of amniocentesis or CVS, is considered safe and efficacious (Thomas et al., 2000). Efforts to find new markers, including the possibility of circulating free DNA in the maternal circulation, are currently underway.

\section{REFERENCES}

Chasen, S.T., Perni, S.C., Kalish, R.B., Chervenak, F.A., 2007. First-trimester risk assessment for Trisomies 21 and 18 in twin pregnancy. Am. J. Obstet. Gynecol. 197, 374-374.

Elias, S., Gerbie, A., Simpso,. J.L., Nadler, H.L., Sabbagha, K.E., Shkolnik, A., 1980. Genetic amniocentesis in twin gestations. Am. J. Obstet. Gynecol. 138, 169-174.

Jacob, C., 2011. Prenatal screening for trisomy 21: Recent advances and Guidelines. Clin. Chem. Lab. Med. 49, 12.

Sin, I.L., Tan, T.Y.T., 2009. Down syndrome in monochorionic twins. Singap. Med. J. 50, 264-267.

Thomas, M., Jenkins, J., Ronald, J., Wapner, R.J., 2000. The challenge of prenatal diagnosis in twin pregnancies. Curr. Opin. Obstet. Gynecol. $12,87-92$.

Wright, D., Syngelaki, A., Staboulidou, I., Cruz, J.J., Nicolaides, K.H., 2011. Screening for trisomies in dichorionic twins by measurement of fetal nuchal translucency thickness according to the mixture model. Prenat. Diagn. 31, 16-21. 